\title{
RELAÇÃO DE GÊNERO E SEXUALIDADES NAS LETRAS DE MÚSICA: O QUE NOS DIZEM OS/AS DISCENTES?
}

\section{JOSEVAL DOS REIS MIRANDA}

Doutor em Educação. Professor da Universidade Federal da Paraíba, Centro de Educação, Departamento de Metodologia da Educação e Professor do Programa de Mestrado Profissional em Letras - PROFLETRAS/UFPB, na unidade Mamanguape, Campus IV- Litoral Norte.

\section{ALYSSON COSTA FEIJÓ DA SILVA}

Mestre em Letras pela Universidade Federal da Paraíba - PROFLETRAS. Graduado em Letras pela Universidade Federal da Paraíba. Especialista em Língua, Língua e Literatura pela CINTEP/PB.

Professor nas escolas públicas Colégio Municipal Waldecyr Cavalcanti de Araújo Pereira (Pedras de Fogo-PB) e Colégio Municipal Prof. Nivaldo Xavier de Araújo (Itambé-PE).

\begin{abstract}
É inegável que há muitas diferenças nos comportamentos de meninos e meninas. Reconhecêlas e trabalhar para não transformá-las em desvantagens é papel de todo educador. (BRASIL, $1998 b, p .322)$
\end{abstract}

\begin{abstract}
RESUMO
O objetivo do presente artigo é analisar como as músicas ouvidas pelos/as alunos/as dos Anos Finais do Ensino Fundamental influenciam sua compreensão sobre as relações de gênero e sexualidades. As referências teóricas se constituíram a partir de três eixos: Relação de gênero e sexualidades, fundamentado nos estudos de Louro (1997; 2007), Carvalho e Rabay (2015), Bourdieu (2012); Os gêneros discursivos/textuais fundamentados em Bakhtin (2011), Marcuschi (2008), Koch e Elias (2012), Cavalcante (2016); e Letra de música, fundamentado com Tatit (1997; 2002; 2004), Silva; Borges (2014). Os três eixos também receberam contribuição de documentos oficiais como: a Lei de Diretrizes e Bases da Educação Nacional no 9394/96 e as orientações dos Parâmetros Curriculares Nacionais - PCN - língua portuguesa e apresentação dos temas transversais (1998a; 1998b). A pesquisa seguiu a abordagem qualitativa, baseada em pesquisa participante, fazendo uso de instrumentos de geração de dados como: observação participante, roda de conversa e questionário. A análise dos dados gerados ocorreu por meio da Análise do Discurso de acordo com os estudos de Maingueneau. Foram participantes da pesquisa dezessete estudantes de uma turma de $8^{\circ}$ ano do Ensino Fundamental: nove estudantes do sexo feminino, sete do masculino e um estudante que designou-se "neutro". Os participantes estavam regularmente matriculados/as em uma escola pública municipal da cidade de Pedras de Fogo - PB. O resultado da análise de dados revelou que o processo educacional e cultural baseado nos princípios androcêntricos se mostrou muito forte nas concepções sobre sexualidades, sobretudo no que se refere às relações de gênero e nos alunos e alunas da turma participante.
\end{abstract}

Palavras-chave: Relação de gênero e sexualidades. Língua Portuguesa. Gênero textual; Letra de música.

GENDER RELATIONS AND SEXUALITIES IN MUSIC LIRICS: WHAT DO MALE AND FEMALE STUDENTS HAVE TO SAY ABOUT IT? 


\begin{abstract}
The aim of the present article is to analyze how music heard by male and female students enrolled in the Final Years of Elementary School influence their understanding about gender relations and sexualities. The theoretical references lie on three axes: Gender relations and sexualities, which is substantiated by Louro (1997; 2007), Carvalho and Rabay (2015), Bourdieu (2012); Discursive/textual genres, which are substantiated by Bakhtin (2011), Marcuschi (2008), Koch and Elias (2012), Cavalcante (2016); Music lyrics, which are substantiated by Tatit (1997; 2002; 2004), Silva; Borges (2014). These three axes are also fed by official documents such as: Lei de Diretrizes e Bases da Educação Nacional (Law Guidelines and Bases of National Education) n. 9394/96, guidelines of Parâmetros Curriculares Nacionais - PCN (National Curricular Parameters) Portuguese language and presentation of cross-sectional topics (1998a; 1998b). The research followed the qualitative approach based on participatory activities; data generation instruments were used in the study, namely: participatory observation, conversation rounds and questionnaires. Data analysis was performed through the Discourse Analysis according to Maingueneau's studies. Seventeen (17) students enrolled in the $8^{\text {th }}$ year of the elementary school: 9 females, seven males and one student who designated itself as "neutral". All participants were enrolled in a public school of Pedras de Fogo County, Paraíba State. Data analysis results have shown that the education and cultural processes based on androcentric principles seem to be stronger in concepts about sexualities, mainly when it comes to gender relations, to male and female students participating in the study.
\end{abstract}

Keywords: Gender relations and sexualities. Portuguese Language. Textual genre. lyrics.

\title{
RELACIÓN DE GÉNERO Y SEXUALIDADES EN LAS LETRAS DE LAS CANCIONES: LO QUE NOS DICEN LOS/LAS ESTUDIANTES
}

\section{RESUMEN}

En este artículo tenemos como objetivo analizar como las canciones escuchadas por los/las alumnos/as de los Años Finales de la Educación Fundamental influencian en su compresión sobre las relaciones de género y sexualidades. Las referencias teóricas se constituyeron a partir de tres hechos: Relación de género y sexualidades, fundamentada en los estudios de Louro (1997;2007); Carvalho e Rabay (2015), Bourdieu (2012); Los géneros discursivos/textuales fundamentados con Bakhtin (2011), Marcuschi (2008), Koch y Elias (2012), Cavalcante (2016); y Letra de canciones fundamentado con Tatit $(1997 ; 2002$; 2004), Silva; Borges (2014), los tres hechos también recibieron contribuciones de documentos oficiales como: la Ley de Directrices y Bases de la Educación Nacional $n^{\circ}$ 9394/96, las orientaciones de los Parámetros Curriculares Nacionales PCN - lengua portuguesa y presentación de los temas transversales (1998a; 1998b). En el aspecto metodológico la investigación fue estructurada de acuerdo a un abordaje cualitativo, por medio de la pesquisa participante, haciendo uso de instrumentos de generación de datos como: la observación participante, la rueda de conversación y el cuestionario. El examen de los datos generados se realizó por medio del Análisis del Discurso de acuerdo con los estudios de Maingueneau. Fueron participantes de la pesquisa diecisiete estudiantes del aula de $8^{\circ}$ año de la Educación Fundamental: nueve estudiantes del sexo femenino, siete del masculino y una estudiante que afirma ser "neutro", regularmente matriculados/as en una escuela pública municipal de la ciudad de Pedras de Fogo-PB. El resultado del análisis de los datos reveló que el proceso educativo y cultural, basado en los principios androcéntricos se evidencio notablemente en las concepciones sobre sexualidades; principalmente, en lo concerniente a las relaciones de género, en los alumnos y alumnas del salón participante.

Palabras clave: Relación de género y sexualidades. Lengua Portuguesa. Género textual. Letra de canciones. 


\section{Primeiras palavras}

Este trabalho surgiu de nossas inquietações acerca das questões de gênero e sexualidade no contexto de sala de aula. Desse modo, a partir da vivência de um dos autores como professor de Língua Portuguesa nos Anos Finais do Ensino Fundamental e de um deles como orientador no Programa de Mestrado Profissional em Letras, buscamos analisar como as músicas ouvidas por alunos e alunas dos Anos Finais do Ensino Fundamental influenciam suas relações de gênero e sexualidades.

A atuação profissional nas turmas dos Anos Finais do Ensino Fundamental possibilitou a percepção de que uma parte considerável dos/as alunos/as não compreendia o texto lido de forma satisfatória; havia a sensação de estar-se formando analfabetos/as funcionais, de acordo com o Indicador Nacional de Alfabetismo Funcional-INAF ${ }^{1}$. Compreendemos também que as atividades relacionadas à interpretação de texto, embora sejam parte da constituição dos livros didáticos de Língua Portuguesa, muitas vezes são tratadas com pouco interesse por parte dos/as colegas professores/as, principalmente por aqueles/as que não tiveram formação específica em Letras, talvez por preferirem atividades gramaticais; ou mesmo por aqueles/as que não exploram outros pontos de vista em relação ao texto e que limitam-se à leitura e ao entendimento superficial por parte dos/as alunos/as - É mais fácil! E, consequentemente, menos trabalhoso.

Portanto, ao observar o trabalho em sala de aula, percebemos que alguns dos/as alunos/as dão-se por satisfeitos/as ao atingirem o nível mais elementar da leitura, a saber: a extração de significado da superfície do texto. Dentre as alegações apresentadas quando deparam-se com questões que vão além da mera decodificação, ouvimos: "O texto é muito grande, professor!", "Eu já respondi à pergunta número 1. Pergunte a outro!", "Eu não gostei desse texto.", e, as que mais doeram em nossos(as) ouvidos foram: "Eu não entendi o texto, professor!", "Eu já sei ler!".

Mesmo que a escola tenha desenvolvido no/a aluno/a as habilidades necessárias para a leitura - ainda que para uma leitura superficial - alguns/mas podem até dizer ela cumpriu o papel de ensinar a ler foi cumprido. Apesar de limitar-se à mera decodificação, a leitura superficial também é importante, pois deve ser a primeira etapa para uma leitura mais aguçada capaz de possibilitar a compreensão do real sentido das palavras, dos textos e ideias, - assim, o aluno poderá, ou não, concordar com o que lê. Ou seja, a leitura não é mais vista exclusivamente como mera decodificação, mas como um processo atrelado a práticas sociais.

A partir da perspectiva cognitivista de leitura Solé (1998, p. 22) diz que "a leitura é um processo de interação entre o leitor e o texto". Contudo, essa interação entre leitor e texto ficará seriamente comprometida se o leitor (no caso, o/a aluno/a) não conseguir compreender o texto lido. Pensando de forma semelhante, Leffa $(1996$, p. 11) afirma que "quando o leitor diz 'li, mas não entendi', ele [...] olhou, mas não viu. Houve a tentativa de leitura, mas não houve a leitura"; seja durante a leitura de um texto escrito ou oral ou de letras das músicas cantadas e ouvidas por alunos e alunas.

Quando referimo-nos às letras das músicas que esses/as jovens ouvem e reproduzem em seus dispositivos eletrônicos, percebemos a violência nas palavras, a qual é, muitas vezes, direcionada à figura feminina, seja por meio de palavras grosseiras e de desrespeito

\footnotetext{
${ }^{1}$ Sobre o Indicador Nacional de Alfabetismo Funcional-INAF e os seus relatórios ver mais em https://ipm.org.br/inaf
} 
velado ou, até mesmo, explícito. Essa é a realidade observada nos corredores e salas de aula de algumas turmas com as quais trabalhamos. No meio social, tal violência manifestase de várias formas, da quebra de objetos até o ato sexual forçado, a exposição da vida íntima, humilhação, agressão física e feminicídio ${ }^{2}$.

Assim, a pesquisa que deu origem a esse texto nasceu da realidade vivida em sala de aula, da observação acerca do fato de que os/as alunos/as parecem reproduzir, e/ou serem influenciados, pela violência e pelo desrespeito presentes em algumas letras das músicas ouvidas em seus aparelhos eletrônicos. A desconsideração para com os/as demais colegas e os/as professores/as é facilmente percebida.

Em alguns casos, os estudantes parecem não conseguir compreender as palavras presentes em tais músicas. A leitura da letra das canções sequer chegava a ser feita, como constatamos em conversa informal com alguns/mas deles/as. Incomoda-nos ver que alguns/mas alunos/as, mesmo passando por um processo de alfabetização, não apresentam a desenvoltura necessária em leitura, e/ou em compreensão de texto, tampouco compreendem as músicas que cantam.

Diante do quadro geral apresentado, reafirmamos que o objetivo de nossa pesquisa foi analisar como as músicas ouvidas por alunos (as) dos Anos Finais do Ensino Fundamental influenciam suas relações de gênero e sexualidades. Tal proposta foi desenvolvida durante as aulas de Língua Portuguesa ministradas em uma turma do $8^{\circ}$ ano do Ensino Fundamental de uma escola pública municipal situada na cidade de Pedras de Fogo-PB.

Não poderíamos deixar de mencionar que seguimos a abordagem qualitativa, baseada em pesquisa participante. Utilizamos como procedimentos/ instrumentos geradores de dados o questionário, a roda de conversa e a observação participante. Foram participantes da pesquisa dezoito estudantes: seis do sexo masculino e onze do feminino. Vale ainda ressaltar que um(x) $\mathrm{d}(\mathrm{x}) \mathrm{s}$ participantes autodeclarou-se "neutro". El(x) foi aqui identificado pelo nome social Bruce - todos os nomes dos/as participantes mencionados aqui são fictícios dada nossa preocupação com a preservar suas identidades.

Inicialmente, o presente artigo aborda algumas reflexões acerca das questões de gênero e sexualidades; em seguida, debate as relações de gênero, sexualidade, identidades e relações com o poder. Prosseguindo, o artigo tece considerações a respeito dos gêneros discursivo/textual e relaciona-os com as letras de música. Por fim, apresenta os dados gerados na pesquisa para provocar "novas" reflexões sobre atividades relacionadas a questões de gênero e sexualidade em letras de músicas.

\section{Gênero e sexualidades na escola}

De acordo com os Parâmetros Curriculares Nacionais ${ }^{3}$, do terceiro e quarto ciclos do Ensino Fundamental - temas transversais: orientação sexual (BRASIL, 1998b), doravante

\footnotetext{
${ }^{2}$ Ver mais em: http://www.planalto.gov.br/ccivil_03/_ato2015-2018/2015/lei/L13104.htm Lei que endurece a pena para crimes de feminicídios; https://www.mapadaviolencia.org.br/ Mapa da Violência 2015 mostra dados sobre homicídios de mulheres no Brasil; https://www12.senado.leg.br/institucional/omv/entenda-aviolencia/a-violencia-contra-a-mulher; http://www.cidh.org/Basicos/Portugues/m.Belem.do.Para.htm A Convenção Interamericana dos Direitos Humanos apresenta em seu Artigo $1^{\circ}$ a definição da violência contra as mulheres; entre outros.

${ }^{3}$ Utilizamos os Parâmetros Curriculares Nacionais como orientação curricular para a nossa pesquisa, uma vez que à época (de abril a outubro de 2017) a Base Nacional Comum Curricular ainda não havia sido aprovada e sancionada.
} 
PCN: Orientação Sexual -, discussões sobre a necessidade de implementar temas ligados às sexualidades tomaram força a partir da década de 1970, pois foram um reflexo das novas formas dos jovens e de outros grupos sociais dos anos 1960 enxergarem as diversas sexualidades.

Contudo, a discussão em salas de aula dos Anos Finais do Ensino Fundamental sobre tais temas passou a ser oficial nas escolas e a fazer parte dos currículos complementares (temas transversais) das aulas a depois que os Parâmetros Curriculares Nacionais foram formulados. De acordo com esse documento, tais discussões tomaram corpo em sala de aula devido à preocupação dos/as educadores/as com o crescimento do número de gravidezes indesejadas na adolescência e com a ameaça incontrolável da contaminação pelo vírus HIV/AIDS na década de 1980.

Embora tenha aberto espaço para a discussão de temas relacionados às sexualidades, o documento (PCN: Orientação Sexual) parece privilegiar a heteronormatividade como visão a ser seguida pelas escolas, pois trata a homossexualidade como tema polêmico. Concomitantemente, os professores/as tendem a associar comportamentos sexuais às normas e regras eleitas por uma determinada sociedade, conforme trecho a seguir:

[...]. Se, por um lado, sexo é expressão biológica que define um conjunto de características anatômicas e funcionais (genitais e extragenitais), a sexualidade é, de forma bem mais ampla, expressão cultural. Cada sociedade desenvolve regras que se constituem parâmetros fundamentais para o comportamento sexual das pessoas. [...]. Preocupa-se então mais intensamente com as diferenças entre os sexos, não só as anatômicas, mas todas as expressões que caracterizam o homem e a mulher. A construção do que é pertencer a um ou outro sexo se dá pelo tratamento diferenciado para meninos e meninas, inclusive nas expressões diretamente ligadas à sexualidade e pelos padrões socialmente estabelecidos de feminino e masculino (BRASIL, 1998b, p. 295-296).

Mesmo instituídos culturalmente dentro dessa ótica binária e heteronormativa, os PCN - Orientação Sexual - deixam uma fresta para que outras possibilidades de relacionamentos, tanto sexuais quanto de gênero, fossem discutidas em sala de aula. Aliás, ao considerar a sexualidade na infância e adolescência, o documento afirma que a puberdade é "a fase de novas descobertas e novas experimentações, podendo ocorrer às explorações da atração e das fantasias sexuais com pessoas do mesmo sexo e do outro sexo" (1998b, p. 296); em se tratando de uma "fase", entende-se que ela será superada.

Contudo, as primeiras ideias sobre gênero apresentadas pelo documento, seguem a lógica do padrão binário homem/mulher, masculino/feminino. Os PCN - Orientação Sexual - atestam que tais "padrões são oriundos das representações sociais e culturais construídas a partir das diferenças biológicas dos sexos, e transmitidas através da educação, o que atualmente recebe a denominação de relação de gênero" (BRASIL, 1998b, p. 296). Afirmando, em seguida, que as ditas representações são internalizadas e que servirão como referências fundamentais na construção identitária dos (as) crianças e dos/as jovens.

Nesse sentido, Bastos e Andrade (2016) afirmam que:

[...] o argumento dos PCN privilegia a percepção da sexualidade enquanto resultado da natureza e da biologia dos seres humanos, ao passo que dispensam aspectos que envolvem a pluralidade de experiências e a importância de sua diversidade cultural. Quando entram na escola, as questões de gênero e sexualidade aparecem intimamente ancoradas na 
lógica heteronormativa, ou seja, onde apenas a experiência heterossexual, pautada no binarismo homem/mulher é reconhecida e verdadeira (BASTOS; ANDRADE, 2016, p. 29).

Como é possível perceber, existem dois pontos a serem retomados acerca das ideias de Bastos e Andrade (2016): primeiro, os PCN - Orientação Sexual - não dispensam os aspectos que envolvem essa pluralidade de experiências no trabalho em sala de aula, mas, chamam tais experiências de "experimentações". Assim, o documento dá a entender que se trata de algo passageiro, de uma "fase". O documento ainda afirma que "A experimentação dos vínculos tem relação com a rapidez e a intensidade da formação e da separação de pares amorosos entre os adolescentes" (BRASIL, 1998b, p. 296). Todavia, se a "sexualidade é, de forma mais ampla, uma expressão cultural, cada sociedade desenvolve regras que tornam-se parâmetros fundamentais para o comportamento sexual das pessoas" (BRASIL, 1998b, p. 295).

O desenvolvimento de tais regras leva, então, ao segundo ponto a ser discutido sobre a fala dos pesquisadores Bastos e Andrade, a saber: se é a sociedade que desenvolve as regras e os parâmetros para o comportamento sexual das pessoas, concordamos com os pesquisadores ao afirmarem que "apenas a experiência heterossexual, pautada no binarismo homem/mulher é reconhecida e verdadeira" (BASTOS; ANDRADE, 2016, p. 29); em outras palavras, direcionar uma identidade heterossexual significa guiar historicamente uma sociedade dominante.

Pode parecer estranho aos olhos de uns o fato de buscarmos os PCN - Orientação Sexual - como fonte primeira para definição de relações de gênero. Portanto, queremos, em nossa defesa, alegar que esse foi o documento enviado pelo MEC à escola cuja pesquisa foi feita, bem como às demais escolas públicas brasileiras, e que discorre "sobre a postura do educador e da escola, descrevendo, para tanto, as referências necessárias à atuação educacional ao tratar do assunto, trabalho que se diferencia do tratamento da questão no ambiente familiar" (BRASIL, 1998b, p. 287). Em muitas escolas, os PCN são a única fonte orientadora do fazer do/a professor/a.

De acordo com o exposto, o/a professor/a não deve se negar a trabalhar questões de gênero e sexualidades, não só porque os documentos oficiais estabelecem tais questões como diretrizes a serem trabalhadas em sala de aula, mas, sobretudo, por conta do próprio papel social da escola, a saber: promover a formação integral da pessoa humana e do/a profissional em educação.

\section{Gêneros, sexualidades e identidades}

É sabido que a identificação de gênero é, muitas vezes, pautada em padrões estabelecidos cultural e socialmente; contudo, tal identificação dá-se através de um processo que perpassa a sensação de pertencer a um determinado gênero, ou não. Pensando nesse processo de identificação, a rede social mais acessada no mundo - Facebook ampliou, no ano de 2014, suas opções de gêneros sexuais de dois (masculino ou feminino), conforme os padrões heteronormativos, para um leque de 56 denominações de gênero, a fim de que usuários(as) sintam-se confortáveis quando da necessidade de identificarem seu gênero.

Em seu artigo digital, Caparica (2014) destaca que "A rede social, entre outras coisas, passará a usar os pronomes adequados para cada identidade de gênero escolhida. Ainda não sabemos quando isso vai se estender a nós, lusófonos, mas torcermos para que 
seja logo". Essa urgência também se manifesta em orientações mais atuais; assim, entendemos que os PCN - Orientação Sexual - legitimam as atividades dos/as professores/as focadas em discussões sobre a sexualidade humana. Contudo, o documento está prestes a completar 20 anos e ainda precisa de atualizações.

Hoje percebe-se que uma parcela da sociedade carece e clama por espaço, por visibilidade. Há um grupo de pessoas que não consegue identificar-se com o padrão binário heteronormativo imposto social e culturalmente, o qual é corroborado pelos PCN Orientação Sexual - e, em alguns casos, pelas próprias instituições de ensino.

Estamos de acordo com o pensamento de Caparica (2014) acerca da multiplicidade de gêneros, quando afirma que "costuma-se tratar o sexo como se houvesse apenas duas opções, macho e fêmea, mas esse sistema é insuficiente para entender as características sexuais de toda a população mundial". Não só no que tange as denominações sexuais, mas, sobretudo, a própria identidade de gênero ${ }^{4}$.

A respeito dessa necessidade de classificar, ou não, as pessoas de acordo com o gênero, Louro (2007), ao comentar os estudiosos que tratam de temas como gênero e sexualidade, diz:

[...] para sermos sinceros, nem nós mesmos compreendemos de um modo único o que vem a ser gênero ou sexualidade. Mas essa diversidade, que pode, aos olhos de uns, parecer catastrófica, também pode, aos olhos de muitos, ser saudada como indicadora da vitalidade e da contemporaneidade dos campos teóricos e políticos a que nos dedicamos (LOURO, 2007, p. 205).

A assertiva da autora sinaliza para a inevitável e permanente discussão a respeito de gêneros e sexualidades ${ }^{5}$, a qual deve ser inserida nas diversas áreas das Ciências e, também, nos ambientes escolares da Educação Básica, e não unicamente nas pesquisas e nos estudos desenvolvidos em âmbito acadêmico. Haja vista o ser humano ser constantemente modificado e atualizado por espaços, pelo tempo e por movimentos sociais, a estudiosa aponta que a discussão sobre essas diferenças pode significar uma contínua renovação.

O próprio volume dos Parâmetros Curriculares Nacionais dedicado ao ensino da Língua Portuguesa nos Anos Finais do Ensino Fundamental recomenda a combinação de temas de estudo nas aulas de Língua Portuguesa e de outras matérias escolares. $\mathrm{O}$ documento destaca que:

A língua, sistema de representação do mundo, está presente em todas as áreas de conhecimento. A tarefa de formar leitores e usuários competentes da escrita não se restringe, portanto, à área de Língua Portuguesa, já que todo professor depende da linguagem para desenvolver os aspectos conceituais de sua disciplina. (BRASIL, 1998a, p. 31).

\footnotetext{
${ }^{4}$ De acordo com o Livro de conteúdo da formação profissional em Gênero, orientação sexual e relações étnico-raciais - Gênero e diversidade na escola - GDE, a identidade de gênero diz respeito à percepção subjetiva de ser masculino ou feminino, conforme os atributos, os comportamentos e os papéis convencionalmente estabelecidos para homens e mulheres (BRASIL, 2009).

${ }^{5}$ Tomamos o termo Sexualidades no plural por acreditar que, assim como não há apenas duas formas para se referir aos gêneros, a sexualidade humana é fator de interação entre as pessoas e que as relações sexuais vão além do binário homem e mulher. Se para Louro (1997, p. 24) há "múltiplas formas que podem assumir as masculinidades e as feminilidades", assim, consideramos cabível e plausível a utilização do termo em sua forma plural.
} 
Uma vez cientes de que a língua é um fator de união, inclusive no trato de temas diversos a serem trabalhados nas escolas, professores (as) orientados pelos parâmetros Curriculares, devem se unir em um trabalho que integre as diversas áreas do conhecimento.

Não é o caso de, como muitas vezes ocorre em projetos interdisciplinares, atribuir à Língua Portuguesa o valor meramente instrumental de ler, produzir, revisar e corrigir textos, enquanto outras áreas se ocupam do tratamento dos conteúdos. Adotar tal concepção é postular a neutralidade da linguagem, o que é incompatível com os princípios que norteiam estes parâmetros. Um texto produzido é sempre produzido a partir de determinado lugar, marcado por suas condições de produção. Não há como separar o sujeito, a história e o mundo das práticas de linguagem (BRASIL, 1998a, p. 40).

A par da necessidade de estabelecer uma reciprocidade entre as várias matérias escolares, voltemos, pois, à discussão acerca do conceito de gênero. Aliás, a imprecisão no conceito de gênero, também é destacada por Carvalho e Rabay (2015), quando discorrem sobre a crescente visibilidade dos estudos sobre gênero no campo educacional brasileiro, a partir da década de 1990. Na época

[...], portanto, o discurso educacional e acadêmico ainda não incorporou, ampla e rigorosamente, o conceito de gênero originalmente veiculado pela teorização feminista: gênero como construção social e cultural, estrutura e relação de desigualdade, marcador de identidade dominante/dominada, subjetividade. Gênero não se transversalizou nos currículos [...] (CARVALHO; RABAY, 2015, p. 121-122).

Percebemos que o caminho para uma definição do termo gênero vai além dos limites iniciais da constituição biológica como o determinante comportamental e sexual do indivíduo ou mesmo de padrões heteronormativos que estabelecem o conceito binário macho/fêmea. A noção de gênero deve ser caracterizada por um conjunto de fatores que consideram, entre outras coisas, a pluralidade de experiências do indivíduo, de seus desejos seu processo de identificação como ser histórico, e seu reconhecimento do processo de construção social.

A utilização do argumento biológico para distinguir homens de mulheres e, consequentemente, para impor o "masculino" em detrimento do "feminino", é citada por muitos/as estudiosos/as como, por exemplo, Louro (1997), ao afirmar que:

$\mathrm{O}$ argumento de que homens e mulheres são biologicamente distintos e que a relação entre ambos decorre dessa distinção, que é complementar e na qual cada um deve desempenhar um papel determinado secularmente, acaba por ter o caráter de argumento final, irrecorrível. Seja no âmbito do senso comum, seja revestido por uma linguagem "científica", a distinção biológica, ou melhor, a distinção sexual, serve para compreender - $e$ justificar - a desigualdade social (LOURO, 1997, p. 20-21).

$\mathrm{O}$ argumento de considerar-se o fator biológico como determinante das relações construídas histórica e socialmente, também é criticado por Bourdieu quando afirma que "A divisão entre os sexos parece estar 'na ordem das coisas', como se diz por vezes para falar do que é normal, natural, a ponto de ser inevitável” (Bourdieu, 2012, p. 17). 
Não há como negar que a figura feminina é vista como 'inferior' ao longo da história humana, e, assim, refletida no discurso do senso comum. De acordo com a cosmogonia hebraico/cristã, a mulher foi criada da costela de um homem, o primeiro elemento (o homem) deu origem ao segundo (a mulher). Em outras palavras, a mulher derivou-se do homem. Outro exemplo dessa concepção de 'inferioridade' feminina pode ser observado na figura clássica da posição do coito sexual no qual o homem coloca-se "por cima" da mulher. Existe, ainda, a limitação do espaço doméstico, no qual a mulher deve estar na cozinha, sem mencionar a ojeriza à figura da 'presidenta' da república. Enfim, nossa história está repleta de temerosos exemplos da imposição da situação de 'inferioridade' feminina. Com relação à configuração dos corpos e o ato sexual, Bourdieu afirma:

[...] em cima ou embaixo, ativo ou passivo, essas alternativas paralelas descrevem o ato sexual como uma relação de dominação. De modo geral, possuir sexualmente [...] é dominar no sentido de submeter a seu poder, mas significa também enganar, abusar ou, como nós dizemos 'possuir (BOURDIEU, 2012, p. 29).

Contudo, o "caráter fundamentalmente social das distinções baseadas no sexo" é reclamado pelo uso mais recente do termo "gênero" por feministas norte-americanas, como destaca Scott. A autora afirma ainda que "A palavra indicava uma rejeição do determinismo biológico implícito no uso de termos como 'sexo' ou 'diferença sexual"" (SCOTT, 1995, p. 72).

Ao longo da História, a figura feminina tem sido posta em segundo plano no jogo de relações sociais e políticas dos seres humanos. Como destaca Louro, "intelectuais, estudantes, negros, mulheres, jovens, enfim, diferentes grupos que, de muitos modos, expressam sua inconformidade e desencanto em relação aos tradicionais arranjos sociais e políticos, [...], à discriminação, à segregação e ao silenciamento" (1997, p. 15-16). Assim, questões de gênero tomaram espaço nas universidades e nas escolas.

"Tornar visível" a mulher que fora/é segregada social e politicamente tem sido a bandeira de estudos feministas e os PCN - Orientação Sexual - deram grande contribuição para esses estudos. Essa dinâmica de segregação é chamada por Bourdieu (2012) de "princípio androcêntrico", segundo o qual a sociedade é organizada de cima para baixo, ou seja, o homem/masculino ocupa a posição superior e a mulher/feminino, a inferior.

Louro (1997) destaca ainda que o caráter político defendido pelos estudos feministas tem/tinha como objetivo efetuar mudanças em questões sociais sobre as mulheres, fato que recoloca essas questões no campo das relações entre sujeitos sociais. A autora diz que "As justificativas para as desigualdades precisariam ser buscadas não nas diferenças biológicas [...], mas sim nos arranjos sociais, na história, nas condições de acesso aos recursos da sociedade, nas formas de representação" (1997, p. 22).

Se é "no âmbito das relações sociais que se constroem os gêneros" (LOURO, 1997, p. 22), os estudos feministas devem se debruçar, prioritariamente sobre as mulheres, mas, também, sobre os homens, a fim de evitar generalizações. Os estudos devem levar em consideração os momentos históricos e as características de cada sociedade na construção do conceito de gênero,

O que ocorre é, então, uma importante transformação nos Estudos Feministas - transformação esta que não se faz sem intensas discussões e polêmicas. Vale notar que, implicado lingüística e politicamente no debate anglo-saxão, o termo não poderia ser simplesmente transposto 
para outros contextos sem que sofresse, também nesses novos espaços, um processo de disputa de ressignificação e de apropriação (LOURO, 1997, p. 23).

Observando a citação acima apresentada, é possível notar que o gênero é um fator da constituição do sujeito; assim, é possível entender os sujeitos como seres plurais, portadores de múltiplas identidades, pertencentes a diferentes grupos (étnicos, sexuais, de classe, de gênero e políticos). Logo, o fator de identificação do sujeito perpassa os conceitos de sexo/gênero, e leva o sujeito a identificar-se também como branco/preto, rico/pobre, alto/baixo, gordo/magro, de direita/de esquerda, dominante/dominado, heterossexual /homossexual/bissexual etc.

Louro destaca que "é importante que notemos que grande parte dos discursos sobre gênero de algum modo incluem ou englobam as questões de sexualidade" (1997, p. 25). Tomando-se o princípio androcêntrico de Bourdieu, compreende-se as fortes referências ao órgão sexual masculino nas relações de gênero. Para ele:

[...] o falo, sempre presente metaforicamente, mas muito raramente nomeado e nomeável, concentra todas as fantasias coletiva de potência fecundante. À maneira das filhoses ou da massa folhada, que se come no momento dos partos, das circuncisões, do nascer dos dentes, ele "cresce", ou ele "se levanta". O esquema ambíguo do enchimento é o princípio gerador dos ritos de fecundidade que, destinados a fazer crescer mimeticamente (o falo e o ventre da mulher), pelo recurso sobretudo a alimentos que inflam e fazem inflar, se impõem nos momentos em que a ação fecundadora da potência masculina deve se exercer, como nos casamentos - e também por ocasião do início das lavouras, tempo de uma ação homóloga de abertura e fecundação da terra (BOURDIEU, 2012, p. 20-21).

Assim, a relação de gênero foi pautada na referência do órgão masculino e de sua virilidade, bem como nos papéis sociais de cada um. O homem, tal qual o seu sexo, é exterior, ereto, visível, pulsante, cheio de vida; é aquele que fecunda, é motivo de orgulho... para a mulher. Semelhantes ao seu sexo, mulheres são voltadas para dentro, para baixo, escondidas, inertes, além de receberem a vida, são fecundadas. Tal fato pode ser causa de vergonha, por isso, elas devem manter as pernas fechadas

De acordo com Louro (1997), a sexualidade pode ser exercida de diferentes formas, a saber: por meio de prazeres e desejos corporais/sexuais. Assim, para a autora, a construção das identidades sexuais de cada um, dar-se-á, "pois, através das formas como vivem sua sexualidade, com parceiros/as do mesmo sexo, do sexo oposto, de ambos os sexos ou sem parceiros/as" (1997, p. 26). A pesquisadora destaca ainda que homens e mulheres identificam-se como 'masculino' ou como 'feminino' durante o processo de construção histórica e social; portanto, constroem suas identidades de gênero dessa forma.

A identidade de gênero pode se apresentar como: agênero, andrógino, bigênero, cisgênero, genderqueer, gênero fluido, gênero variante, intersex, pangênero e transgênero, uma vez que é passível de ser construída social e historicamente. Acertadamente, o sítio de relacionamento virtual facebook atualizou as possibilidades de gênero e ampliou o cenário de identificação por parte de seus/suas usuários.

\section{Gêneros e sexualidades como formas de poder}


Não se pode negar que tanto em aspectos relativos a gêneros quanto naqueles relativos às sexualidades, as identidades não estão em estado de repouso e que o indivíduo as toma em um rompante e as usa, veste-as. O processo de identificação de gênero ou sexualidade é resultado de uma construção; dessa forma, o sujeito vai moldando, (re)construindo, sua identidade, a qual não permanece sempre na mesma posição dentro do processo de modificações pessoais que ocorrem ao longo da vida.

Sobre isso, Louro diz que

Em suas relações sociais, atravessadas por diferente discursos, símbolos, representações e práticas, os sujeitos vão se construindo como masculinos ou femininos, arranjando e dessaranjando seus lugares sociais, suas disposições, suas formas de ser e de estar no mundo. Essas construções e esses arranjos são sempre transitórios, transformando-se não apenas ao longo do tempo, historicamente, como também transformando-se na articulação com as histórias pessoais, as identidades sexuais, étnicas, de raça, de classe [...] (LOURO, 1997, p. 28).

Se essas relações estão pautadas em arranjos socialmente definidos, certamente temos relacionado os discursos, as representações e as práticas sob a batuta de regras heteronormativas. Assim, acreditamos que muitos/as, inclusive nos primeiros anos do século XXI, não conseguiram respeitar/aceitar arranjos sexuais diferentes do que lhes foi imposto socialmente; ou seja, homem/mulher. "Dado o fato de que é o princípio da visão social que constrói a diferença anatômica e que é esta diferença socialmente construída que se torna o fundamento e a caução aparentemente natual da visão social que a alicerça" (BOURDIEU, 2012, p. 20).

Esses padrões heteronormativos estão profundamente arraigados e expressam-se até mesmo de forma sutil; ou seja, as formas de poder instituídas pelos padrões heteronormativos não se dão exclusivamente do homem em direção à mulher, mas também, dos homens e mulheres heterossexuais em direção a homens e mulheres homossexuais. E mais, existem"feministas que percebem o conceito como extremamente marcado por sua origem acadêmica, branca, de classe média" (LOURO, 1997, p. 34),

Essa forma de poder é definida por Bourdieu (2012) como violência simbólica; para ele, tal violência não se limita à violência física: ela é expressa, aceita e reproduzida, por instituições como família, igreja, as escolas e o Estado; , além de dar-se pela "concordância entre as estruturas objetivas e as estruturas cognitivas, entre a confirmação do ser e as formas do conhecer, entre o curso do mundo e as expectativas a esse respeito, que torna possível esta referência ao mundo" (2012, p. 17).

A violência descrita por Bourdieu (2012) pode ser representada por atos como a defloração da noiva, a progenitura masculina abundante, o ato de trair a esposa, o ato de dar ao filho homem o nome do pai ou do avô (geralmente paterno), o homem poder sentarse de pernas abertas. Por outro lado, a mulher deve sentar-se de pernas fechadas e aceitar casar-se com determinado homem em função de sua posição social. Entretanto, como já antecipamos, a dominação, a violência e o uso do poder expressos por diferenças não ocorrem exclusivamente do homem para com a mulher, como é condensado no trecho a seguir:

[...] ela também está carregada da afirmação da diferença entre as mulheres.

Relacionada, a princípio, às distinções biológicas, a diferença entre os gêneros serviu para explicar e justificar as mais variadas distinções entre 
mulheres e homens [...]. A diferença entre as mulheres, reclamada, num primeiro momento, pelas mulheres de cor, foi por sua vez, desencadeadora de debates e rupturas no intrior do movimento feminista. Com o acréscimo dos questionamentos trazidos pelas mulheres lésbicas, os debates tornaram-se ainda mais complexos, acentuando a diversidade de histórias, de experiências e de reivindicações de muitas (e diferentes) mulheres" (LOURO, 1997, p. 45).

A relação de poder quer perpetuar as desigualdades, sejam elas representadas ou não, por mulheres e homens homossexuais e/ou bissexuais, fato que é justificado pelas construções instáveis da identidade sexual ${ }^{6}$ e de gênero, as quais e entrepassam fatores como classe social, raça, religião, idade, nacionalidade e partido político.

Em linhas gerais, a relação de poder entre gêneros ou entre sexos ignora que a construção de identidades humanas é múltipla e que tanto homens quanto mulheres possuem masculinidades e feminilidades diversas daquelas impostas hegemonicamente. A forma como as sociedades heterossexuais, brancas, de classe média, tratam os "diferentes" visa apenas manter os privilégios, mesmo que, para tanto, obriguem homossexuais/bissexuais e, principalmente, a figura da mulher à subordinação histórica.

Após termos traçado pontos importantes acerca das relações de gênero e sexualidades - tais como discussões sobre o tema nas escolas, a partir de items da PCN Orientação Sexual -, bem como a necessidade de discussões mais atuais,- identificamos o fato de a identidade de gênero e sexual não ser definida unicamente por fatores biológicos, mas, sobretudo, por fatores sociais. Por fim, é importante relembrar que o gênero sexual é o que determina a relação de poder nas sociedades.

A seguir apresentaremos a relação dessa temática com o ensino da Língua Portuguesa, em especial no que diz respeito ao genero discursivo/textual letra de música.

\section{O ensino da Língua Portuguesa baseado em diversos gêneros discursivos/textuais}

Considerando que todo processo de comunicação humana realiza-se por meio de gêneros discursivos/textuais, e que "para boa parte das crianças e dos jovens brasileiros, a escola é o único espaço que pode proporcionar acesso a textos escritos, textos estes que se converterão, inevitavelmente, em modelos para a produção" (BRASIL, 1998a, p. 25), acredito que apresentamos aqui argumentos que justificam o uso dos gêneros discursivos/textuais nas aulas de Língua Portuguesa.

Para Marcuschi, "sempre que ensinamos algo, estamos motivados por algum interesse, algum objetivo, alguma intenção central, o que dará o caminho para a produção tanto do objeto como da perspectiva" (2008, p. 50-51). Diante dos vários e possíveis aspectos que podem ser estudados sobre a língua portuguesa, núcleo do presente estudo, o "trabalho será com a língua no contexto da compreensão, produção e análise textual" (MARCUSCHI, 2008, p. 55). Porém, em função de diversos fatores, somente levamos em consideração dois desses aspectos: a compreensão e a análise textual.

\footnotetext{
${ }^{6}$ De acordo com o Livro de conteúdo da formação profissional em Gênero, orientação sexual e relações étnico-raciais - Gênero e diversidade na escola - GDE, a identidade sexual refere-se a duas questões diferenciadas: por um lado, é o modo como a pessoa se percebe em termos de orientação sexual; por outro lado, é o modo como ela torna pública (ou não) essa percepção de si em determinados ambientes ou situações. A identidade sexual corresponde ao posicionamento (nem sempre permanente) da pessoa como homossexual, heterossexual ou bissexual, e aos contextos em que essa orientação pode ser assumida pela pessoa e/ou reconhecida em seu entorno (BRASIL, 2009).
} 
Uma ideia semelhante à apresentada por Marcuschi (2008) é encontrada nos Parâmetros Curriculares Nacionais - terceiro e quarto ciclos de Língua Portuguesa - no qual, ao argumentar sobre a leitura de textos escritos, afirma:

A leitura é o processo no qual o leitor realiza um trabalho ativo de compreensão e interpretação do texto, a partir de seus objetivos, de seu conhecimento sobre o assunto, sobre o autor, de tudo o que sabe sobre a linguagem etc. Não se trata de extrair informação, decodificando letra por letra, palavra por palavra. Trata-se de uma atividade que implica estratégias de seleção, antecipação, sem as quais não é possível proficiência (BRASIL, 1998a, p. 69).

Em ambos os recortes, percebemos que o foco do ensino deve residir nos usos da língua, ou como propõe Bakhtin (2011), no estudo de materiais linguísticos concretos. Ao entendermos que já na infância dominamos as regras de uma língua e a capacidade de nos comunicar, caberá à escola não ensinar o que o/a aluno/a já sabem, mas, sim, os "usos da língua e formas não corriqueiras de comunicação escrita e oral" (MARCUSCHI, 2008, p. $55)$.

Seguindo as indicações e argumentos apresentados até aqui, esta pesquisa se propôs a trabalhar com o gênero letra de música. Um dos motivos para a escolha desse gênero foram as situações concretas vividas em sala de aula, as quais causaram-nos inquietação quanto ao modo como os/as alunos/as interagiam com a música que ouvem/ouviam, bem como quanto a forma como reagem/reagiam ao escutá-la/cantá-la.

\section{O gênero discursivo/textual letra de música}

A utilização de letras de música como atividade escolar tem ultrapassado os limites do lúdico na Educação Infantil. Nos Anos Iniciais do Ensino Fundamental, são usadas como ferramenta para auxiliar a alfabetização assim como nos Anos Finais do Ensino Fundamental atingiram níveis mais elevados de leitura por meio de atividades dirigidas e chegaram a ganhar espaço em livros didáticos através de atividades de interpretação de texto. O uso da música em sala de aula ganhou mais espaço a partir da abertura do currículo escolar devido à implementação dos Parâmetros Curriculares Nacionais - terceiro e quarto ciclos do ensino fundamental: Língua Portuguesa (1998a), doravante PCN: Língua Portuguesa.

A seção dos PCN - Língua Portuguesa (1998a) - trata dos Objetivos do Ensino Fundamental e é um dos motivos para usar letras de música em atividades em sala de aula. Consta nos objetivos que os/as alunos/as sejam capazes de

Utilizar as diferentes linguagens - verbal, musical, matemática, gráfica, plástica e corporal - como meio para produzir, expressar e comunicar suas ideias, interpretar e usufruir das produções culturais, em contextos públicos e privados, atendendo as diferentes intenções e situações de comunicação (BRASIL, 1998a, p. 7-8).

Ao sinalizar que a linguagem musical faça parte da matriz curricular do Ensino Fundamental, os PCN - Língua Portuguesa (1998a) - abriram espaço para que letras de canções sejam fossem em sala. Tal fato é mais um motivo para trabalhar a letras de música em atividades propostas por professores. Inclusive, os Parâmetros (1998a) apresentam uma "tabela que organiza os gêneros privilegiados para o trabalho" (BRASIL, 1998a, p. 53) e 
classificam a canção como gênero literário em linguagem oral, o qual é o foco desta pesquisa.

Sendo assim, queremos retomar os objetivos concernentes à leitura de textos escritos, de acordo com os Parâmetros Curriculares Nacionais de Língua Portuguesa para os Anos Finais do Ensino Fundamental:

[...] seleção de procedimentos de leitura em função dos diferentes objetivos e interesses do sujeito (estudo, formação pessoal, entretenimento, realização de tarefas) e das características do gênero e suporte;

[...] levantamento e análise de indicadores linguísticos e extralinguísticos presentes no texto para identificar as várias vozes do discurso e o ponto de vista de determinado tratamento dado ao conteúdo, com a finalidade de:

- confrontá-lo com o de outros textos;

- confrontá-lo com outras opiniões;

- posicionar-se criticamente diante deles; (BRASIL, 1998a, p. 55/7).

Consideramos, assim, o gênero letra de música como de interesse dos/as alunos/as, uma vez que diversas vezes os observamos deleitando-se com os versos de suas músicas preferidas. Ademais, consideramos necessário perceber o ponto de vista apresentado sobre as relações de gênero e sexualidades nas letras das canções ouvidas pelos/as alunos/as participantes da pesquisa para confrontá-los com outras opiniões. Para tanto, os/as convidamos a posicionarem-se criticamente diante deles.

Existem outros fatores que precisam ser levados em consideração com relação ás letras de músicas como gênero discursivo/textual, dentre eles, a diversidade textual e o crescimento do número de textos apresentando aspectos multimodais. Silva e Borges (2014) defendem que:

É com base nessa diversidade textual e na multimodalidade de texto que se deve considerar a música como um gênero textual. A música [...] como todo e qualquer texto, possui fatores únicos de textualidade que só um gênero textual possui [...], características fundamentais que irão agir na produção do seu sentido, variando de acordo com o meio em que é produzido, em que é sentido e interpretado (SILVA; BORGES, 2014, p. $53)$.

Outro fator para reconhecer-se a letra de música como gênero discursivo/textual A interação leitor-texto destacada por Solé (1998) e reforçada por Ferreira (2013, p. 17) é outro fator a justificar classificação das letras de música como gênero discursivo/textual. Ferreira (2013, p. 17) afirma que "nunca devemos esquecer que a música é, além da arte de combinar os sons, uma maneira de exprimir-se e interagir com o outro, e assim devemos compreendê-la.". Portanto, consideramos que sua aplicação em sala de aula durante atividades estruturadas deva/devesse ser um procedimento de uso rotineiro; tanto em exercícios programados pelos/as professores/as, quanto em atividades programáticas descritas nos livros didáticos:

O gênero textual canção é muito presente nos materiais didáticos, portanto, é utilizado como objeto de ensino e aprendizagem da prática discursiva dos alunos. Uma de suas características composicionais é a fusão de duas semioses distintas: a linguagem verbal e a linguagem 
musical. Dessa forma, espera-se que a canção, como todos os demais gêneros existentes e abordados pela escola, seja processada na íntegra, ainda que o objeto maior de estudo seja o discurso, recorrendo assim apenas à linguagem verbal. (RAMIRES et al. 2010, p. 23-24).

De acordo com os/as autores/as acima, não há como negar o papel das letras de música como gênero discursivo/textual, seja pela interação que desperta entre leitor e texto, ou por auxiliar o processo de alfabetização. Enfim, não se pode deixar de notar que esses e outros fatores evidenciam sua multimodalidade, principalmente, sua importância no campo de atividades da área de Ciências Humanas. Assim, a letra de música passa a ser um instrumento para interpretação textual, pois dá a oportunidade de conhecermos a nós mesmos, aos outros ao mundo.

Como afirma Bakhtin (2011, p. 261), "Todos os diversos campos da atividade humana estão ligados ao uso da linguagem. Compreende-se perfeitamente que o caráter e as formas desse uso sejam tão multiformes quanto os campos da atividade humana". Ainda segundo o autor, é a alternância dos falantes que determina os limites dos enunciados; a resposta do "outro" está atrelada à ativa compreensão responsiva. Dessa feita, acreditamos que, ao comunicarem-se com os textos, os/a alunos/as estabelecem um diálogo real, o qual é a forma mais simples e clássica de comunicação discursiva. Logo, as atitudes dos/as alunos/as quanto as mensagens transmitidas através das letras das músicas são uma atitude responsiva.

Ainda segundo Bakhtin (2011) tal atitude figura como um elo na cadeia da comunicação discursiva, pois vincula-se a outras obras (outros enunciados, outros textos). Em qualquer situação, o seu limite se dará na alternância entre os sujeitos do discurso; dessa forma, cada enunciado deve ser visto como uma "resposta" aos enunciados que the precederam, uma vez que é impossível para o indivíduo definir sua posição de sujeito sem correlacioná-la com outras posições.

Assim, a expressão do enunciado, em maior ou menor grau, exprime a relação do falante (o texto) com os enunciados do outro, (o/a leitor/a). Dessa forma, esse processo reflete os ecos da alternância dos sujeitos do discurso - o estilo de cada um. Em outras palavras, nossas próprias ideias nascem e formam-se no processo de interação com os pensamentos dos outros; ou seja, quando um enunciado é criado por um falante, os elos que ligam o texto ao leitor, ainda não existem. Desde o início, o enunciado constrói-se a partir de atitudes responsivas; dessa forma, o papel dos "outros" torna-se essencial para a construção do enunciado.

Essa alternância, ou melhor, a relação entre música e ouvinte, resulta em uma atitude responsiva, e só tende a crescer. Ademais,

A canção brasileira ocupa hoje um espaço artístico amplo demais para permanecer desvinculada de qualquer esfera de reflexão no país. Há todo um aparato industrial, tecnológico e mercadológico cuidando de sua produção e aumentando seu poder de penetração nos diversos setores socioculturais sem que haja, em contrapartida, qualquer acompanhamento analítico em condições de desvendar ao menos uma parcela desses estratos de sentido que a canção movimenta diariamente (TATIT, 2002, p. 309-310).

Dentre os espaços ocupados pela música, encontra-se o ambiente escolar, pois ela está sempre presente em apresentações festivas, em projetos escolares, em comemorações 
de datas especiais, no lúdico, como ferramenta para auxiliar a alfabetização, em atividades de interpretação textual; enfim, não se pode negar que a música domina a esfera escolar. Mesmo quando não é trazida pelos alunos (as), fara-se presente através de diversas atividades propostas pela própria escola.

A citação anterior faz referência à indústria da música. Os alunos e alunas, de maneira geral, já têm mais consciência da dinâmica de consumo musical neste período de transição entre a vida infantil e a adulta, alguns/mas deles/as já encontram-se até inseridos no mercado de trabalho; contudo, nesta pesquisa, focamos na relação entre letra de música e aluno/a. Tatit (2002), ao falar sobre o cantar dos/as intérpretes, diz que:

A entoação despe o artista. Revela-o como simples falante. Rompe o efeito de magia. Nivela sua relação com o ouvinte. As tensões melódicas fazem do artista um ser grandioso que se imortaliza no timbre. A amplificação da voz e sua equalização junto aos demais instrumentos reforçam sua dignidade e imprimem um tom de magia, necessário ao encanto que excede no ouvinte (TATIT, 2002, p. 13-14).

Tomado pelo "canto da sereia" o/a jovem se vê refletido no comportamento de seu/sua intérprete favorito/a, bem como nas letras das músicas que ouve e canta. Não é à toa o fervor dos (as) fãs diante de seu/sua artista favorito/a.

O processo de identificação, de ver-se no outro, de espelhar-se nas canções, nos trejeitos, no modo de vestir e de se comportar é a base de nossa formação como seres sociais. Portanto, o fato de gostarmos, ou não, de determinada música e/ou artista faz todo sentido para nós, seres humanos. O mesmo comportamento também é visto no/a artista e em sua música.

Quem canta sabe que se não recuperar os conteúdos virtualizados na composição, durante o período da execução, deixando transparecer uma inegável cumplicidade com o que está dizendo (o texto) e com a maneira de dizer (a melodia), simplesmente inutiliza o seu trabalho e se desconecta do ouvinte. Não há canção sem impressão enunciativa, sem a sensação de que o que está sendo dito está sendo dito de maneira envolvida. Por isso, o reconhecimento dos cantores e de seus estilos é por si só, um fator de credibilidade e confiança (TATIT, 1997, p. 89).

A identificação do/a jovem com seu/sua artista preferido/a se dá de forma que o/a ouvinte passa a vestir-se e comportar-se de maneira semelhante à do/a artista de sua preferência. O envolvimento será maior, quando o/a jovem identifica temas de seu interesse nas letras das músicas destes/as intérpretes.

Como esta pesquisa visa compreender as músicas pela percepção dos/as alunos/as, voltamos a reafirmar que fatores como arranjo musical, ritmo, melodia, etc., não foram levados em consideração em nossa análise: o foco foi dado exclusivamente nas letras das músicas. A seguir, apresentaremos os dados da pesquisa relativos à percepção dos/as discentes com relação às questões de gênero e sexualidades a partir do conteúdo nas letras das músicas ouvidas por eles/as.

\section{A percepção discente quanto às relações de gênero e sexualidades expressas nas letras de música}


Para nos auxiliar nas interpretações dos dados gerados, Utilizamos as palavras de Maingueneau (1995) para substanciar as interpretações dos dados gerados. Ele traça um paralelo entre sua vida de escritor e seu fazer artístico ao destacar que:

O preconceito supõe que um homem se torna autor se possui o dom de "exprimir" esteticamente seus sofrimentos e suas alegrias. Nessa concepção, existiram por um lado às experiências da vida, por outro, flutuando em algum éter, as obras que pretensamente os representam de maneira mais ou mesmo disfarçada. Cabe então à história literária tecer correspondência entre as fases da criação e os acontecimentos da vida. Na realidade, a obra não está fora de seu "contexto" biográfico, não é o belo reflexo de eventos independentes dela. Da mesma forma que a literatura participa da sociedade que ela supostamente representa, a obra participa da vida do escritor. O que se deve levar em consideração não é a obra fora da vida, nem a vida fora da obra, mas sua difícil união (MAINGUENEAU, 1995. p. 46).

As indicações utilizadas por Maingueneau (1995) referem-se ao autor de literatura canônica; contudo, sentimo-nos à vontade para, mais uma vez, associar o escritor de texto literário ao escritor de letra de música, obviamente, resguardadas suas peculiaridades. Não temos por objetivo, questionar os ditames subjetivos da estética, mas associá-los, pois, em certos aspectos, as histórias narradas nos textos literários, bem como nas letras das músicas, parecem "imitar" a vida de seus autores, uma vez que o modo de ser de cada um está "longe de ser exterior à obra, participa da criação" (MAINGUENEAU, 1995. p. 46).

Essa associação parece importante porque a admiração direcionada aos artistas, principalmente aos mais populares, de forma geral, leva em consideração sua imagem, seu modo de ser, como já mencionado aqui. Para além de fatores musicais técnicos, como ritmo e harmonia, necessários para compor-se uma letra da música, compositores também se valem de suas experiências, de seu modo de ser e perceber a vida. Tais fatores são decisivos no momento da escolha das palavras para os versos.

Dado o fato de a presente pesquisa ter focado as letras das músicas e dispensando, por exemplo, os aspectos melódicos delas, encontramos um forte obstáculo: a preferência e observância dos alunos(as) por determinados estilos musicais de ritmos agitados, alegres e dançantes. Ao justificar porque gosta de certas músicas, a aluna Manu resume a opinião da maioria dos alunos (as) da turma: "Por que é legal o ritmo e a letra, dependendo da letra".

Sua frase foi eleita por nós como a 'fala da turma', como se uma grande parcela dela tivesse escolhido Manu para resumir o pensamento de todos (as) os (as) participantes. À primeira vista, pode-se pensar que as letras das músicas não foram um fator preponderante para a preferência da turma. E, de fato, não o foi!

Os estilos musicais Sertanejo, Funk, Reggae e Pop foram os mais escolhidos, principalmente por apresentarem ritmos agitados e dançantes. Sobre o estilo Funk, o aluno Irineu reconhece que suas letras podem ser ofensivas: "transmite umas mensagens não muito educativa"; sobre as músicas do estilo Sertanejo, a aluna Tayna afirma que gosta: "Porque são animadas e a letra é bem legal, algumas as letras são legais"; a aluna Ester prefere o estilo Pop "Por que me deixa com alto astral". Enfim, para os/as alunos/as participantes, a letra da música pode ficar em segundo plano desde que a música tenha um ritmo envolvente.

Mesmo antes de ouvir a primeira música tocada para a turma participante da pesquisa (Maria de Vila Matilde, interpretada por Elza Soares), a aluna Tayna dispara: “A música 
era pra ser mais animada, meio...”, e ao som dos primeiros acordes, o aluno Júlio vibra: “É massa a música!". A satisfação dos/das participantes durante os encontros era mais pulsante quanto mais agitada fosse a batida da música, por outro lado, se a melodia não fosse convidativa a movimentos frenéticos, o desânimo era notável.

O gosto musical da turma não impediu os/as alunos (as) de tecerem comentários sobre as letras das músicas que compuseram o corpo da pesquisa. E, para melhor espelhar as percepções dos alunos e alunas acerca das relações de gênero e sobre as sexualidades presentes nas letras das músicas analisadas, usamos as respostas dos questionários, os discursos nas rodas de bate-papo, bem como as próprias letras das músicas. Os relatórios gerados a partir da Observação Participante e das escritas dos/as alunos/as geradas através de pesquisas feitas por eles (as) também, foram utilizadas.

O gênero discursivo/textual letra de música, como parte do discurso musical, é visto aqui como uma forma de expressão utilizada pelos (as) alunos (as) que participaram da pesquisa. Trazemos algumas considerações sobre as letras das músicas analisadas e sobre as percepções dos/as alunos/as a respeito das relações de gênero e sexualidades presentes nelas.

A oposição entre elementos de euforia e disforia comentadas anteriormente também foi observada pelos (as) alunos (as) em algumas letras de música. No que se refere à música Maria de Vila Matilde (interpretada por Elza Soares), a mulher retratada recebe os adjetivos 'valente' e 'corajosa' (Ela teve coragem), mas também o oposto disfórico 'covarde' (subentendido) diante de sua decisão de enfrentar o homem agressor.

\section{$[\ldots]$}

Aluno Júlio - Tem algumas mulheres que têm medo de falar, aí fica quieta no canto. Mas daqui não. Daqui tá dizendo que a mulher é valente, que não tem medo de....de se expressar.

[...]

Aluno Júlio - É que as mulheres, as mulheres têm muito medo de enfrentar o homem. Mas nessa música aqui, não. Esta daqui está dizendo que é uma mulher muito valente.

Professor - Vocês concordam com isso?

Alunos e alunas ((em vozes sobrepostas)) - Sim! Concordo!

Aluna Tayna - Ela teve coragem.

[...]

(Fonte: Dados do pesquisador. Transcrição Roda de Conversa 2, 2017).

A condição de "valente" e "corajosa" - como termos eufóricos para retratar a mulher - alçou a mulher na letra da música a níveis mais altos. Por um momento, durante a discussão, os(as) alunos(as) colocam a figura feminina em uma posição de "superioridade". Mesmo que a condição de "superioridade" não tenha tomado corpo explicitamente na fala dos/as participantes, o termo subentendido assumiu a posição de par oposto através de termos e/ou expressões disfóricos, expressos ou subentendidos, que qualificaram o homem, como: "foi ameaçado", "dando uma chance pra ele", "digno de pena":

$$
\text { [...] }
$$

Professor - Ela ligou mesmo?

Aluno Júlio - É não, ela falou que ia ligar. ... é...: ela ameaçou ligar. Ela falou: "eu vou ligar pra 180".

Aluno Léo - Praticamente dando uma chance pra ele. 
$[\ldots]$

Aluno Júlio - Para fazer medo pra ela, né! Pra ele, na verdade.

Aluna Tayna-Mas ela ficou com pena dele, para ele não ser preso. Disse que ia ligar para ele sair de dentro de casa logo.

[...]

(Fonte: Dados do pesquisador. Transcrição Roda de Conversa 2, 2017).

Essa condição momentânea de superioridade feminina também foi comentada pelos (as) alunos (as), pois estava expressa nos versos da terceira estrofe da música:

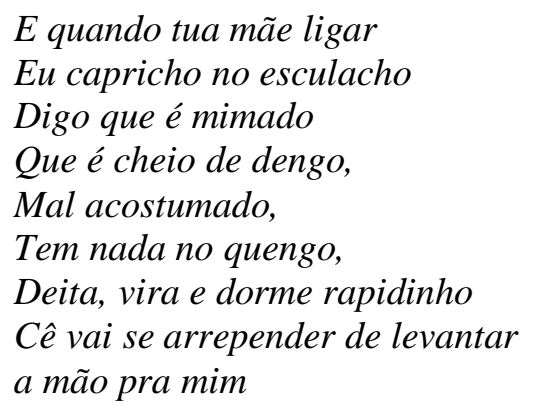

A discussão entre os alunos e alunas chega ao ponto em que o comportamento da mulher cantada por Elza Soares é interpretado como um ato vingativo, realizado pela mulher com a intenção de punir o marido: "Tipo ela... ela se vingou. Porque ele é... tipo, bateu nela e ela entregou tudo o que sabia dele" (aluna Amanda). Não só a aluna Amanda acreditou na vingança, o aluno Josicleydson crê que a vingança só estará completa quando o homem também sofrer por uma agressão física. Como mostra o trecho a seguir:

$[\ldots]$

Professor - Na letra da música tem algum outro tipo de agressão? Sem ser agressão física, que vocês estão me mostrando?

Aluna Amanda - Acho que tem...

Aluno Josicleydson - Ela diz que vai ligar pra mãe dele...

Professor - Por que que ela vai ligar pra mãe do cara?

Alun@ Bruce/Batman - Porque a mãe do cara vai defender ele.

Aluno Josicleydson - Ligar pra mãe do cara é pior do que ligar pra polícia, rapaz!!! ... É a única que pode bater nele!

[...]

(Fonte: Dados do pesquisador. Transcrição Roda de Conversa 2, 2017).

De acordo com o pensamento expresso pelo aluno Josicleydson, é a mulher quem fará a ligação telefônica para a mãe do marido com a intenção de devolver a agressão, pois, segundo ele, a mãe punirá o homem. Tal punição seria uma forma de agressão moral provocada pela esposa, uma vez que 'apanhar' da mãe é pior do que 'apanhar' da polícia. Entre aqueles (as) que se manifestaram sobre a canção, apenas@ alun@ Bruce/Batman percebe que a mãe sairá em defesa do filho no momento da discussão.

De acordo com suas falas, podemos entender que, no que toca à produção de sentido a partir dos estudos de Maingueneau (2015), o aluno Josicleydson não captou nos versos que é a mãe que partiria em defesa do filho, e que a esposa agredida alega - através de um "capricho no esculacho" - que o comportamento de seu esposo deriva de um processo educacional e, sobretudo, cultural.

A agressividade esperada por Josicleydson demonstra um "traço" da personalidade masculina (ou, reclamada como essencialmente masculino). Para combater a violência 
sofrida pelo companheiro, a mulher, segundo ele, teria que recorrer a tal expediente. Ao estudar as abordagens de análise dos gêneros, Scott (1995) mostra que a teoria psicanalítica limita o conceito de gênero à esfera doméstica e familiar e lança o seguinte questionamento: "Como podemos explicar, no interior dessa teoria, a persistente associação entre masculinidade e poder, o fato de que se valoriza a virilidade do que a feminilidade?" (SCOTT, 1995, p. 82).

A "virilidade masculina" expressa através da força física impõe à mulher uma condição de submissão, a qual é representada pelas agressões impingidas, pelos pais, irmãos, namorados e maridos. Esse mecanismo de controle e dominação tem sido empregado há muito, ainda que sob outras nuances, pois tem como objetivo consumar o poder do homem sobre a mulher (ou sobre aquele em situação de inferioridade).

[...] em todas essas circunstâncias, os governantes emergentes legitimaram a dominação, a força, a autoridade central e o poder dominante como masculinos (os inimigos, os forasteiros, os subversivos e a fraqueza como femininos) e literalmente traduziram esse código em leis que puseram as mulheres no seu lugar (interditando-lhes a participação na vida política, declarando o aborto ilegal, impedindo o trabalho assalariado das mães, impondo códigos de trajar para as mulheres) (SCOTT, 1995, p. 91).

As formas de submissão feminina têm se manifestado de diversas maneiras na história da humanidade, inclusive o significado de alguns termos traz consigo o ranço da dominação. Não só a língua portuguesa derivou da Roma Antiga. De acordo com o conceito de pater familias, o homem tinha direito e poderes ilimitados sobre a mulher, os filhos e os escravos; todos eram vistos como bens. De acordo com esse processo cultural e educativo "A mulher é do homem. A mulher é propriedade do homem" (aluno Irineu).

A fala do aluno Irineu ecoa os períodos da história e cultura da humanidade quando um bebê era abandonado por ter um defeito físico ou pelo simples fato de ter nascido do sexo feminino. Afinal, como resumiu Sêneca, um dos principais filósofos gregos: "É preciso separar o que é bom do que não pode servir para nada". O filho homem era valorizado, principalmente, nas civilizações antiga e medieval, por deter a responsabilidade de manter a linhagem da família.

A vulnerabilidade feminina diante do sistema androcêntrico instalado e revisitado cultural e socialmente tornou-se banal e, portanto, parte integrante do processo educacional vigente na maioria dos lares brasileiros. Trazemos este pensamento à tona porque a aluna Tayna percebeu que: "às vezes, o filho cresce agressivo muito mais que o pai. Às vezes, quando tem uma mulher, faz a mesma coisa que o pai fazia com a mulher".

A constatação da aluna Tayna é corroborada por dados oficiais, o portal da justiça e cidadania divulgou as vésperas do último dia internacional da mulher que em 2016 houve recorde no número de atendimentos feitos pela Central de Atendimento à Mulher (Ligue 180, um serviço da Secretaria de Serviços para as Mulheres, da Presidência da República), que atingiu a marca de 1.133.354 atendimentos. Entre prestação de informações e encaminhamento para outros serviços, 140.350 atendimentos relataram episódios de violência.

E em $65,91 \%$ dos casos, as violências foram cometidas por homens com quem as vítimas têm ou tiveram algum vínculo afetivo atual ou excompanheiros, cônjuges, namorados ou amantes das vítimas. Os dados 
também apontam para uma triste realidade - a violência de gênero que marca, mutila e mata milhares de brasileiras no âmbito doméstico e familiar também alcança os filhos e filhas das brasileiras (BRASIL, Portal Brasil, 2017).

Em muitos casos, a mulher não se comporta como a "valente" cantada por Elza Soares, mesmo que ela chegue, de fato, a denunciar seu agressor: "Ela podia se vingar se ela ligasse, mas ela num ligou não. Só..." (aluno Júlio). Ainda que uma parcela da população já tenha despertado para a situação da mulher, o processo educativo parece 'fazer de conta' que não percebe tal fato. No âmbito familiar, a mulher envergonha-se e se esconde; no âmbito escolar, o assunto não vem à tona, não há políticas educacionais que tragam uma discussão sincera sobre o tema para dentro dos muros da instituição.

As questões sociais trazidas a debate em sala de aula, geraram dados para esta pesquisa. Como afirma Maingueneau (2015), esses "são fenômenos sociais percebidos em determinado momento como importantes - qualquer que seja a razão -, cujo estudo é considerado necessário por um conjunto de pesquisadores".

Há diversas perspectivas sobre a discursividade, inclusive as que tratam de questões sociais como recorte de estudo, pois " $\mathrm{O}$ interesse específico que rege a análise do discurso é relacionar a estruturação dos textos aos lugares sociais que os tornam possíveis e que eles tornam possíveis." (MAINGUENEAU, 2015, p. 47). Segundo o autor, o objeto da Análise do Discurso são os elementos que unem os funcionamentos textuais à situação de comunicação através das enunciações decorrentes do verbal e do institucional.

Um fato curioso ocorreu ao final da discussão sobre a música que ganhou vida na voz de Elza Soares. Ao pedirmos uma avaliação sobre a Roda de Conversa, os alunos e alunas assumiram um tom de campanha contra a imposição de gênero. Ainda que pontuadas pelo machismo, suas falas conclamam as mulheres a denunciar casos de agressão.

Gostei de ver a interação sobre aula de lá (refere-se ao encontro anterior) sobre gênero e coisa e dessa também que... tipo: mulher $e$ homem, ninguém merece ser espancado. Direitos iguais (aluna Tayna).

Um resumo: Foi que a mulher não deve ser inferior ao homem e também sempre tem que ter um posicionamento pra... ter...: coragem pra denunciar se o homem bater. (aluna Amanda)

Que tenha direitos iguais, não importa a sexualidade, o gênero ou o que ela gosta ou deixa de gostar. Você tem que respeitar a pessoa. (Alun@ Bruce/Batman).

[...]

Aluno Josicleydson - A mulher tem que ser homem! Tem que ter força, tem que ter coragem! Tem que meter na cara mesmo. Tem que pegar a chinela assim, ó! Tá! Meter na cara do safado.

Professor ((provocando)) - Como é o comecinho?

Aluno Josicleydson - A mulher tem que ser homem!

Aluna Tayna - A mulher tem que ser mulher e homem tem que ser homem. Entendam. Homem é homem e mulher é mulher. Agora, ninguém é superior a ninguém. Tem que ser igual.

Aluna Manu - Por que mulher tem que ser homem? ((como que sem aceitar a colocação do colega)). 
Aluno Léo ((tentando explicar a colocação do colega de classe)) - Que a mulher tem que ser valente. É isso que ele quis dizer.

Aluna Tayna - Eu espero que quando a gente fique maior a gente, tipo: mude um pouco dessa sociedade que tá machista e tal... com os preconceitos contra as escolhas do povo entre gênero entre sexualidade e que as mulheres parem de sofrer nas mãos dos homens

(Fonte: Dados do pesquisador. Transcrição Roda de Conversa 2, 2017).

As músicas indicadas pelos/as participantes (para o estilo Funk: $O$ grave bater, interpretada por MC Kevinho; e, para o estilo Sertanejo: Eu, você o mar e ela, interpretada por Luan Santana) foram distribuídas previamente, para que fossem lidas e para que gerassem considerações acerca das relações de gênero e sexualidades descritas nelas.

O aluno Júlio manteve sua reprovação em relação às escolhas quando as duas músicas selecionadas foram tocadas durante a Roda de Conversa. Contudo, mesmo que discretamente, ambos as aplaudiram ao término de cada execução. O Funk e o Sertanejo, como estilos musicais, foram a opção da maior parte dos alunos e alunas participantes, dada, segundo opinião deles, sua alegria/diversão e musicalidade. Esses estilos foram a opção de 11 participantes, ou $65 \%$ do total. A defesa desses estilos musicais foi expressa nos depoimentos a seguir.

É assim professor: Essas músicas que eu escolho, não é por causa da letra. É porque o ritmo é bom... o toque é bom. Não por causa da letra. Muita letra é feia. (aluna Ester).

Muita gente ignora a letra da música e só vê o ritmo. A maioria das pessoas escolhe a música só pelo ritmo dela. (...). Às vezes, nem presta atenção na letra. (aluno Léo).

Tipo... a letra pode ser feia, mas o ritmo é bom então eu vou ouvir... (aluna Manu).

É porque tem umas músicas muito rápida. Aí você escuta e não entende nada. A maioria das vezes (aluno Júlio).

(Fonte: Dados do pesquisador. Transcrição Roda de Conversa 3, 2017).

Como afirmado anteriormente, a maior parte dos/as participantes não demonstrou preocupação com as letras das músicas que ouvem, se elas são ofensivas ou se possuem "mensagens não muito educativa"(sic.)(aluno Irineu). Concluímos, portanto, que ambos, alunos e alunas entregam-se a ritmos dançantes, animados e agitados.

Ao mudarmos o estilo musical (Não quero dinheiro - Tim Maia), perceberam que a letra da música não trazia uma carga depreciativa. A aluna Tayna declarou: "Essa música, a letra dela é bonita... a letra é bonita, mas o ritmo não é bonito".

É impossível que as mensagens em tais letras de música não fiquem em suas cabeças, mesmo que não entendam absolutamente nada do que estejam repetindo. Suas respostas demonstram que é só diversão, que a música traz a 'dancinha'... É como se fosse uma prova de que não é preciso entender nada do que a letra da música diz, basta que seja uma música 'pra cima', com ritmo contagiante. Contudo, não podemos afirmar que seja uma música que agrade a todos.

Embora a maioria tenha preferido os estilos Funk e Sertanejo, a escolha não foi unânime, alguns alunos e alunas preferiram não se manifestar quanto às letras e os estilos 
que foram tocados. Porém, antes e depois de cada execução, podíamos ouvir: "Isso não é música também não!" (aluno Júlio), ou "Isso aqui não é música, não!” (aluno Irineu).

Antes mesmo de serem executadas em sala de aula e de suas letras serem lidas, ao receberem as letras das músicas $O$ grave bater (MC Kevinho) e Eu, você, o mar e ela (Luan Santana), a aluna Rafaela e a alun@ Bruce/Batman queixaram-se:

Professor - ((dirigindo-se à Bruce/Batman que já veio reclamar das músicas selecionadas para o próximo encontro)) - Tu já tá querendo resumir, é?

Alun@Bruce/Batman e aluna Rafaela - É claro! As duas... é visto como um objeto sexual, a mulher.

Professor - As duas músicas?

Alun@Bruce/Batman e aluna Rafaela-É!

Alun@ Bruce/Batman - Tanto essa quanto a outra.

Aluna Rafaela - No clip, ele só quer ficar com ela.

Alun@ Bruce/Batman -...A gente é vista como objeto sexual.

(Fonte: Dados do pesquisador. Transcrição Roda de Conversa 3, 2017).

Uma situação um tanto incômoda instaurou-se quando os (as) alunos (as) foram questionados sobre o que pensavam acerca das duas músicas executadas. Por mais que em uma primeira leitura a aluna não tenha entendido "muito bem" a mensagem de uma das letras de música, ela conseguiu perceber que a mulher foi retratada como um ser 'coisificado', disponível para o uso e bel prazer do homem; fatos que são característicos da cultura machista.

A identificação de pares eufóricos e disfóricos passaram a outros níveis ao longo do debate. Por mais que a mulher não tenha tido voz nas duas letras avaliadas, é recorrente a ideia de que tenha dado permissão para o ato sexual; não só permissão, mas que tenha expressado o desejo de praticá-lo. Tal conviç̧ão se deu a partir da vontade do homem, não importando a presença, ou não, do eu lírico feminino. De acordo com esse raciocínio, a permissão, ou vontade dela, não passou de mera suposição.

Duas outras músicas foram executadas como contraponto às anteriores: Não quero dinheiro, de Tim Maia; e Sua cara, interpretada por Pabllo Vittar e Anitta. À execução da música seguiu-se de uma atividade focada em elaborar capas de CDs a partir de imagens retiradas da Internet. As capas deveriam ser elaboradas para um público que não conhecesse a letra da música, mas deveriam ser capazes de transmitir sua mensagem.

A Atividade de produção de capas de CDs solicitava aos/as participantes que redigissem, em grupo, um comentário, uma mensagem sobre a letra da música. Os versos simples e diretos de Tim Maia renderam os dois textos transcritos a seguir.

A mulher é valorizada e é Romântica, Alegre mostra que o casal é Feliz, a mulher é apaixonada Sorridente, Satisfeita A Musica principal fala sobre o amor mutuo entre um casal. Ela não está com ele por interesse e sim por Amor. E ele é Romântico com a Mulher. (Grupo Não quero dinheiro 1: Amanda, Jhennyfer, Natacha e Vivyane).

Muito romântico no enredo musical decorrente da capa mudando a linha de pensamento diferenciado da oficial. Na imagem parece que o casal é muito próximo, parece também que ele valoriza muito ela e faz de tudo pra ela ficar feliz quando ela fica triste e que eles acreditam na promessa 
que fazem quando se casam. (Grupo Não quero dinheiro 2 - Jorge, Rafaela, Bruce, Irineu e Josicleydson).

A visão transmitida, parcialmente, pelas CDs montadas ganhou força com o texto redigido pelos dois grupos, em resumo, rara que a figura feminina seja valorizada, ela precisa da presença de um homem que a faça se sentir assim, ela precisa, de certa forma, estar à sombra de um homem que "faz de tudo pra ela ficar feliz" - para sentir-se satisfeita, a mulher carece de ser fiel às promessas do casamento.

Com a execução e a leitura da música Sua cara - mais uma representante do estilo Funk, interpretada por Anitta e pela Drag Queen brasileira, Pabllo Vittar - fez com que os alunos e alunas da turma de $8^{\circ}$ ano do Ensino Fundamental perceberam uma mudança no percurso narrativo da letra da música. "Essa música é o contrário", preludiou a aluna Tayna, ao perceber que a mulher passou a assumir a posição de sujeito, dona de suas vontades. Contudo, segundo alguns (mas) participantes, ela ainda espera a iniciativa do homem.

Quando parece que os termos agressivos serão esquecidos pela turma, e os ânimos são apaziguados, a discussão sobre a letra da música parece reavivar as agressões à figura feminina. Bastou a mulher reclamar uma posição de igualdade, para que a masculinidade dos alunos em sala de aula fosse ofuscada.

As confrontações e associações seguiram uma linha forte e datada historicamente. Antes mesmo que os garotos tentassem se defender, a aluna Rafaela dispara: "Homem nenhum confessa que é machista". Todos os garotos foram questionados por nós, e todos negaram ser machistas.

Outra representante do estilo musical Sertanejo foi à música Infiel, composta e interpretada por Marília Mendonça. Seu eu lírico feminino apresenta um enredo de fácil assimilação, o qual narra o flagrante físico da traição vista pelos olhos de outra mulher. Suas três estrofes iniciais são dirigidas à amante e as três estrofes (refrão) restantes, são direcionadas ao traidor. A mulher da canção resolve liberar o marido traidor para a amante, e livrar-se, assim, da condição de mulher traída.

A questão da identificação do sexo do narrador foi facilmente resolvida pelos/as participantes. O aluno Josicleydson constata: "Não. Lógico que não. Pela letra, é uma mulher que está cantando. Que está contando a história". Ao ser questionado se faria diferença a música ser cantada por um cantor ou por uma cantora, o aluno é taxativo: "Não. Porque a letra vai ser a mesma".

O sucesso da música no site de compartilhamento de vídeos (YouTube) é inquestionável. Já ultrapassava, na época da pesquisa, a marca dos 420 milhões de visualizações. Seu sucesso está conectado a uma dinâmica compartilhada: a esposa é para o lar, para o trato do esposo e dos filhos, enquanto o homem tem passe livre para quaisquer atividades. É culturalmente aceito que o esposo traia a mulher, pois houve um momento em que casamentos eram arranjados entre famílias e os nubentes sequer demonstravam afeto um pelo outro. Os casamentos eram contratos de interesse comercial e político.

A relação de gênero presente nas músicas analisadas e indicadas pelos alunos e alunas participantes da pesquisa apenas reproduz a condição da mulher vivida na atual sociedade. Seus autores e autoras tornam-se cronistas sociais ao expor as entranhas e mazelas da humanidade ou ao criar fantasias sonoras que maqueiam tais mazelas.

A combinação entre um ritmo envolvente e frases que levam à reflexão pode ser um caminho possível. Por ora, os alunos e alunas participantes da pesquisa estão mais ocupados com os ritmos envolventes. 
A percepção sobre as relações de gênero externada a partir da leitura das letras de música apontam para a formação de uma geração menos estagnada. As alunas, por mais que se sintam envolvidas pelos ritmos das músicas, mostraram-se mais dispostas ao debate e ao questionamento dos papéis sociais de homens e mulheres, independentemente de seus direcionamentos sexuais. Os alunos, por sua vez, mantiveram-se mais presos aos valores androcêntricos, na qualidade de herdeiros de uma cultura e educação machista e patriarcal. Por vezes, sentiam-se acuados quando alguma das alunas levantava a voz contra os posicionamentos que insistem em manter as mulheres em situação inferior ao homem.

A névoa que encobre a discussão sobre as sexualidades e as relações de gênero mostrou-se menos espessa. As oportunidades que surgiram, inspiradas nas letras das músicas, para comentarmos sobre as sexualidades e questões de gênero não foram dispensadas. Entretanto, suas ocorrências não foram citadas por nós, por opção. À medida que essas questões foram surgindo durante as Rodas de Conversas, acabaram fazendo parte do debate de forma natural, como deve ser.

Cabe, mais uma vez, às escolas, abrir espaço para tais debates, os quais devem surgir à medida que necessidades sociais os exijam. A turma em questão não se furtou ao debate, houve um grande respeito pela fala do outro e do não igual.

Ao trabalharmos o gênero discursivo/textual letra de música, na qualidade de professores de língua portuguesa, procuramos sensibilizar os alunos e alunas com questões de gênero e sexualidades, e mostrá-los como essas questões são retratadas nas letras das músicas. Enquanto umas romantizam o processo de exploração da figura feminina (Ai que saudade da Amélia) ou vulgarizam sua imagem ( $O$ grave bater, Na dança do strip-tease, Raimunda), outras cantam poeticamente o encantamento e a beleza feminina (Dora), ou colocam a condição de mulher em pé de igualdade à do homem (Meu Deus), o que a dá o direito de ser sujeito de sua própria história.

As falas dos/as participantes destacadas anteriormente precisam estar mais presentes nas escolas, que alunos "tradicionalistas" passem a buscar adjetivos mais tolerantes para designar o perfil feminino; afinal, "Geni, não foi feita para cuspir".

\section{Considerçãoes finais}

A relação de poder entre os gêneros ou entre sexos ignora que a construção das identidades humanas são múltiplas, e tanto homens quanto mulheres possuem masculinidades e feminilidades diferentes daquelas impostas hegemonicamente. A forma que as sociedades heterossexuais, brancas, de classe média tratam os "diferentes" visa apenas manter privilégios, mesmo que para tal, obriguem, homossexuais/bissexuais e, principalmente, a mulher à subordinações históricas.

A escola, como ferramenta de combate às desigualdades sociais, tem, na figura do/a professor/a, seu/a maior representante na promoção de discussões profícuas acerca de temas normalmente negligenciados pelas famílias dos/as estudantes. e, oO/a profissional consciente deve aproveitar todas as possibilidades para trazer ao debate em sala de aula assuntos de interesse social.

A adolescência, período da vida em que encontram-se os/as estudantes dos Anos Finais do Ensino Fundamental, compreende o ciclo em que as transformações corporais afloram, e que, portanto, demanda adaptações contantes. As significativas mudanças em 
seus corpos impõem a reestruturação de sua imagem e novas relações afetivas, inclusive sexuais.

De posse dos dados gerados, percebemos que os/as alunos/as da turma avaliada carregam em si marcas profundas de uma cultura e de um processo educacional que privilegiam o homem em detrimento da mulher. Ressalvamos que as alunas conseguem perceber mais facilmente a desvalorização imposta socialmente à figura da mulher. Contudo, quando o assunto são as relações de sexualidades, a turma não demonstra restrições no que tange à homossexualidade e/ou a outras formas de expressão da sexualidade humana.

Quando o tema das relações de gênero foi abordado a partir das letras das músicas, a percepção geral apresentada pelos alunos e alunas foi a de que o homem sempre ocupa uma posição superior à mulher, ao passo que a figura da mulher foi representada como inferior, como objeto ou como doméstica. Mais uma vez, as alunas conseguiram se destacar ao apresentarem seus argumentos durante as Rodas de Conversa. A partir das falas apresentadas, percebemos que as sexualidades presentes nas letras de música não foram tratadas como algo à parte do 'ser' humano. Como um todo, a turma apresentou-se respeitosa às diferenças.

Assim sendo, o trabalho de análise das letras de músicas demonstrou as concepções dos alunos e alunas participantes e permitiu-nos vislumbrar outros direcionamentos a serem dados às questões das relações de gênero e sexualidades, assim como reforçar alguns pontos que apresentaram arestas mal encaixadas sobre a temática trabalhada.

\section{Referências}

ANDRADE, Carlos Drummond de. Alguma Poesia. São Paulo: Companhia das Letras, 2013.

BAKHTIN, Mikhail Mikhailovitch. Estética da criação verbal. Prefácio à edição francesa Tzvetan Todorov; Introdução e tradução do russo Paulo Bezerra. 6. ed. São Paulo: WMF Martins Fontes, 2011.

BASTOS, Felipe; ANDRADE, Marcelo. "Ser mulher não tem a ver com dois cromossomos X": impactos da perspectiva feminista de gênero no ensino de Ciências. Revista Diversidade e Educação: Gênero e Ciência. Rio Grande, RS, v. 4 n. 8, p. 56-64, jul./dez. 2016.

BOURDIEU, Pierre. A dominação masculina. Trad. Maria Helena Kühner. - 11. Ed. Rio de Janeiro: Bertrand Brasil, 2012.

BRASIL. Gênero e diversidade na escola: formação de professoras/es em gênero, orientação sexual e relações étnico-raciais. Livro de conteúdo. Versão 2009. - Rio de Janeiro: CEPESC; Brasília: SPM, 2009.

BRASIL. Parâmetros curriculares nacionais: terceiro e quarto ciclos: apresentação dos temas transversais. Brasília: MEC; SEF, 1998 b. 
BRASIL. Secretaria de Educação Fundamental. Parâmetros curriculares nacionais: terceiro e quarto ciclos do ensino fundamental: língua portuguesa. Brasília: MEC; SEF, 1998a.

CAPARICA, Marcio. Entenda as 56 opções de gênero do Facebook. Lado Bi, [s.1.], 21 fev. 2014.

CARVALHO, Maria Eulina Pessoa de; RABAY, Glória. Usos e incompreensões do conceito de gênero no discurso educacional no Brasil. Estudos Feministas, Florianópolis, v. 23, n. 1, p, 119-136, mar. 2015.

FERREIRA, Martins. Como usar a música na sala de aula. 8. ed. $1^{\text {a }}$ reimpressão. - São Paulo: Contexto, 2013. - Coleção como usar na ala de aula.

LEFFA, Vilson Jose. Aspectos da leitura: uma perspectiva psicolinguística. Porto Alegre: Sagra: DC Luzzatto, 1996.

LOURO, Guacira Lopes. Gênero, sexualidade e educação: das afinidades políticas às tensões teórico-metodológicas. Educação em Revista, Belo Horizonte, n. 46, p. 201-218, dez. 2007.

LOURO, Guacira Lopes. Gênero, Sexualidade e Educação: uma perspectiva pósestruturalista - Petrópolis, RJ: Vozes, 1997.

MAINGUENEAU, Dominique. Discurso e análise do discurso; Tradução Sírio Possenti. - 1 ed. - São Paulo: Parábola Editorial, 2015.

MAINGUENEAU, Dominique. O contexto da obra literária. tradução Marina Appenzeller. São Paulo: Martins Fontes, 1995. - Coleção Leitura e Crítica.

MARCUSCHI, Luiz Antônio. Produção textual, análise de gêneros e compreensão. São Paulo: Parábola Editorial, 2008.

RAMIRES, Cíntia Pires de Lemos. et. al. A canção compreendida como gênero textual: observação de sua abordagem no livro didático de língua portuguesa e nas aulas de música. $\mathbf{X}$ Congresso de Educação do Norte Pioneiro. UENP: CLCA. Campus Jacarezinho. Anais 2010.

SCOTT, Joan. Gênero: uma categoria útil de análise histórica. Educação \& Realidade. UFRGS. Porto Alegre. v. 20(2). p. 71-99. jul./dez. 1995.

SILVA, Jéssica Carneiro da; BORGES, Carla Luzia Carneiro. Da análise da música como gênero textual e texto multimodal ao ensino de língua portuguesa. Graduando. Feira de Santana. v. 4. n. 6/7. p. 49-60. jan./dez. 2013.

SOLÉ, Isabel. Estratégias de leitura. Tradução Cláudia Schiling. 6. ed. Porto Alegre: Artmed, 1998.

TATIT, Luiz. Musicando a semiótica: ensaios. São Paulo: Annablume, 1997. 
TATIT, Luiz. O cancionista. 2. ed. São Paulo: Editora da Universidade de São Paulo, 2002.

VELLOSO, Caetano Emanuel Viana Teles (1972). Esse cara. Disponível em: <http://www.caetanoveloso.com. br/> e também em <https://pt.wikipedia.org/wiki/Drama_-_Anjo_Exterminado>. Acesso em: 26 abr. 2017.

Recebido em: 03.03.2019

Aceito em: 24.03.2019 